MT-DP - 2015/55

The association between experiential and material expenditures and subjective well-being: New evidence from Hungarian survey data 
Discussion papers

MT-DP - 2015/55

Institute of Economics, Centre for Economic and Regional Studies, Hungarian Academy of Sciences

KTI/IE Discussion Papers are circulated to promote discussion and provoque comments. Any references to discussion papers should clearly state that the paper is preliminary. Materials published in this series may subject to further publication.

The association between experiential and material expenditures and subjective well-being: New evidence from Hungarian survey data

Authors:

Tamás Hajdu

junior research fellow

Institute of Economics

Centre for Economic and Regional Studies

Hungarian Academy of Sciences

email: hajdu.tamas@krtk.mta.hu

Gábor Hajdu

junior research fellow

Institute for Sociology

Centre for Social Sciences of the Hungarian Academy of Sciences

email: hajdu.gabor@tk.mta.hu

December 2015

ISBN $978-615-5594-23-6$

ISSN $1785377 \mathrm{X}$ 


\title{
The association between experiential and material expenditures and subjective well-being: New evidence from Hungarian survey data
}

\author{
Tamás Hajdu - Gábor Hajdu
}

\begin{abstract}
In the last decade, a number of experiments have stated that spending money on experiences rather than on material goods tends to make people happier. However, the experimental designs used to analyze the relationship between consumption and subjective well-being had several limitations: small and homogeneous samples, a direct question assessing the effect of consumption, and a potential social desirability bias due to the stigmatization of materialism. To reduce these limitations, we used a survey method. In two studies based on survey data from nationally representative samples in Hungary, we estimated linear and non-linear associations of experiential and material expenditures with life satisfaction. Although both experiential and material expenditures were positively associated with life satisfaction, evidence supporting the greater return received when buying experiences was limited. The main difference between experiential purchases and material purchases was that the marginal utility of experiential purchases appeared to be linear, whereas the marginal utility of material purchases was decreasing. Despite the limited differences between the effects of experiential and material purchases, the results of the non-linear estimates indicate that to maximize life satisfaction, an average person should allocate more money to buying experiences rather than material goods.
\end{abstract}

Keywords: subjective well-being, life satisfaction, consumption, experiential purchase, material purchase

JEL classification: I31, D12 


\title{
Élményekre és tárgyakra fordított kiadások kapcsolata a szubjektív jólléttel: új eredmények magyar kérdőíves adatok alapján
}

\author{
Hajdu Tamás - Hajdu Gábor
}

Összefoglaló

Az elmúlt évtizedben számos, kísérleteken alapuló tanulmány jutott arra a következtetésre, hogy az élmények vásárlása nagyobb boldogsággal jár együtt, mint a tárgyak vásárlása. A kutatások módszertanának azonban néhány olyan jellemzője van, ami az eredmények megbízhatóságát csökkenti: a minták kis elemszámúak és homogének, a vásárlások hatását direkt kérdéssel mérik, a materialista személyek negatív társadalmi megítélése miatt torzítottak lehetnek az eredmények. E problémák elkerülése érdekében az élmények és tárgyak vásárlásának szubjektív jólléttel való kapcsolatát kérdőíves adatok segítségével vizsgáljuk. Két magyar reprezentatív kérdőíves adatbázis segítségével lineáris és nem lineáris becsléseket végzünk. Az eredményeink szerint mind az élmények, mind pedig a tárgyak fogyasztása pozitívan korrelál az élettel való elégedettséggel, ugyanakkor az élmények erősebb hatására vonatkozó korábbi eredmények a magyar kérdőíves adatokon nem támaszthatóak alá egyértelmúen. A nem lineáris becslések szerint az élmények és tárgyak vásárlása között a fő különbséget az jelenti, hogy előbbi esetben a marginális hatás konstans, míg utóbbi esetben szignifikánsan csökkenő. Ezekre az eredményekre építve azt is megmutatjuk, hogy egy átlagos személynek az élettel való elégedettséget maximalizáló optimális allokáció esetén többet kellene élményekre és kevesebbet tárgyakra költenie.

Tárgyszavak: szubjektív jóllét, élettel való elégedettség, fogyasztás, élmények, tárgyak

JEL kód: I31, D12 


\section{INTRODUCTION}

A substantial section of the subjective well-being literature addresses the relationship between material welfare and satisfaction or happiness. Since the first study conducted by Easterlin (1974), numerous studies have tried to answer the same question: Does more money make people happier? (Frijters, Haisken-DeNew, \& Shields, 2004; Hajdu \& Hajdu, 2014; Kahneman \& Deaton, 2010; Kahneman, Krueger, Schkade, Schwarz, \& Stone, 2006; Kushlev, Dunn, \& Lucas, 2015; Layard, Mayraz, \& Nickell, 2008; Stevenson \& Wolfers, 2008, 2013). The second wave of studies addressing this topic modified the question to concentrate on whether the types of consumption had an effect on subjective well-being. These results consequently supported the idea that money can buy happiness if it is spent right (Dunn, Gilbert, \& Wilson, 2011; Dunn \& Norton, 2013). One of the main findings was that spending money on experiences rather than on material goods makes people happier (Van Boven, 2005; Van Boven \& Gilovich, 2003).

The studies mentioned above used similar experimental designs. Typically, a small sample of university students were randomly assigned into two groups, and members of one group were asked to think about the most recent experiential purchase they made, and members of the other group were asked to think about the most recent material purchase they made. Participants were then asked to rate how happy this purchase made them. Despite its popularity, this methodology has certain limitations. First, the sample was often small and homogeneous, which weakens the reliability of the findings. Second, because all of the experiments took place in the United States, their results had limited external validity. In addition, as most societies consider materialistic individuals to be selfish and self-centered, participants may have tended to underrate the satisfaction they felt from material purchases to avoid the stigma of materialism. Finally, the participants were asked directly how happy the experiences or material objects made them; this question may have been unfamiliar and thus received superficial and less reliable answers.

In this paper, we aimed to answer the following question: what makes us more satisfied, buying experiences or buying material goods? We sought to contribute an important new perspective on this topic by reducing the limitations mentioned above by using a survey method instead of the usual experimental method. Based on two studies of Hungarian survey data, we estimated the association between experiential and material expenditures and life satisfaction. In Study 1, we used two pooled cross-sectional, nationally representative surveys that contained expenditures and well-being data from more than 6100 Hungarian persons. In Study 2, we analyzed the Hungarian Household Budget Survey, which measures expenditures with more precision. In these databases, expenditures and life satisfaction are not explicitly linked, thus an ex post connection can be made between subjective well-being and the 
purchase of different types of goods. Our paper also estimated the associations using both linear and non-linear models, which is a novel contribution. Based on the survey data, the results of Study 1 showed that life satisfaction was slightly more associated (but not statistically) with experiential purchases than with material purchases (at least at the higher expenditures level), but in Study 2, we found little difference between the effects of material and experiential expenditures. We also found that the marginal utility of material expenditures appeared to be diminishing, whereas the marginal utility of experiential expenditures was constant. In addition, we calculated the optimal allocation of experiential and material expenditures to maximize the life satisfaction of an average person. The results of this exercise showed that a reallocation of expenditures (spending more on experiences) might increase individual well-being. We emphasize that our findings do not indicate that previous results are false positive, but rather they highlight the importance of studying more diverse samples using diverse methods.

The paper is structured as follows. Section 2 reviews the existing literature on the effects of experiential and material purchases on well-being. Section 3 describes the usual experimental method and the survey method used in this paper. Sections 4 and 5 present Study 1 and Study 2, respectively. In Section 6 we discuss our results and the differences from previous studies. Section 7 lists the study limitations, and Section 8 provides a conclusion.

\section{LITERATURE REVIEW}

The first paper that examined the relationship between experiential versus material purchases and subjective well-being was by Van Boven and Gilovich (2003). They defined experiential purchases as "those made with the primary intention of acquiring a life experience: an event or series of events that one lives through", whereas "material purchases are those made with the primary intention of acquiring a material good: a tangible object that is kept in one's possession." (Van Boven \& Gilovich, 2003; p. 1194). Although many purchases are in between the material-experiential spectrum, studies have shown that there are certain types of expenditures that people consider to be a prototypical material or experiential purchase. The most frequently listed examples of material purchases are clothing, electronics and jewelry, whereas the most typical examples of experiential purchases are travel, various tickets and admissions (e.g., to a concert) and outdoor sport activities (Guevarra \& Howell, 2015; Van Boven, Campbell, \& Gilovich, 2010; Van Boven \& Gilovich, 2003).

In Van Boven and Gilovich's study (2003), participants were asked to describe a recent material or experiential purchase and to rate their happiness with that purchase. The authors showed that thinking about experiences made people happier and contributed more to their overall happiness than thinking about material purchases. This result was confirmed by 
numerous studies that used the same experimental methodology (Caprariello \& Reis, 2010, 2013; Carter \& Gilovich, 2010, 2012; Howell \& Hill, 2009; Kumar \& Gilovich, 2015; Millar \& Thomas, 2009; Nicolao, Irwin, \& Goodman, 2009; Rosenzweig \& Gilovich, 2012; Thomas \& Millar, 2013).

There are several reasons why experiential purchases might make people more satisfied.1 First of all, material goods tend to be more comparative than experiences (Carter \& Gilovich, 2010; Howell \& Hill, 2009; Rosenzweig \& Gilovich, 2012); they are more interchangeable, thus it is easier to find competing alternatives. The ease of comparing material goods is especially stressed in the retrospect, when the forgone options are more important in the evaluation of material goods than they are in the evaluation of experiences. For example, after the purchase of a smartphone, it is much easier to compare its features with newer or unchosen smartphones or ones possessed by others than it is to compare a day hiking in the mountains. Because experiences live in our memories and are more unique, the pool of relevant alternatives is smaller. In sum, we are more likely to be concerned with the better or missed options if we buy material goods, and this concern can lead to disappointment. Material purchases are more likely than experiential ones to be positional goods, and thus people are more likely to rate their happiness with material goods by considering other people's possessions (Frank, 2005).2

Second, experiences are more closely connected to the self and to one's identity (Carter \& Gilovich, 2012; Thomas \& Millar, 2013). For example, in a series of experiments, Carter and Gilovich (2012) showed that people kept their experiences physically closer to their self, mentioned their experiences more often in their life stories, stated that experiences portrayed more about a person's true self than material purchases, and were more reluctant to exchange their experiential memories. Based on these results, the authors claimed that experiences are the main building blocks of our self: "we are quite literally the sum total of our experiences" (Carter \& Gilovich, 2012; p. 1304). Thomas and Millar (2013) found that experiential purchases had more impact on the self than material purchases, and they showed that this impact mediated the relationship between purchase type and subjective well-being. This characteristic of experiential purchases can also explain why we more often avoid unfavorable comparisons of experiences and why memories of experiential but not material purchases may become more positive over time (Carter \& Gilovich, 2010).

Experiences also have an inherent social nature (Van Boven \& Gilovich, 2003); they are typically experienced with others, whereas material goods are more often enjoyed alone.

${ }^{1}$ For a detailed review see Gilovich and Kumar (2015).

2 A series of previous studies found that individuals are more concerned with relative position of material things (e.g. car, housing) than experiences (e.g. vacation) (Alpizar, Carlsson, \& JohanssonStenman, 2005; Carlsson, Johansson-Stenman, \& Martinsson, 2007; Solnick \& Hemenway, 1998, 2005). 
Furthermore, we often share our experiences with other people. In addition to the increase in well-being that living through an experience provides, it is also a pleasure to tell the story to our friends. Merely remembering and thinking about an experience brings satisfaction and can foster and improve our social relationships (Howell \& Hill, 2009; Van Boven \& Gilovich, 2003), which are themselves essential to happiness (Demır \& Weitekamp, 2007; Dolan, Peasgood, \& White, 2008; Helliwell \& Putnam, 2004). People are not only more likely to talk about their experiential purchases than material ones (Kumar \& Gilovich, 2015), but they also enjoy conversations about experiences more than ones about material purchases because stories about experiences are more likely to have a narrative structure and can lead to more interesting, engaging conversations (Van Boven, 2005; Van Boven et al., 2010). Consistent with these findings, a study by Caprariello and Reis (2013) concluded that the social nature of experiences is the main reason why buying experiences makes people happier than buying material goods.3

Finally, people adapt more quickly to material goods than experiences. Nicolao, Irwin, and Goodman (2009) examined the adaptation process after material and experiential purchases over a two-week period. In their experiment, subjects who could choose from a pool of small value material objects showed a faster adaptation than subjects who chose from the same value experiences.

\section{TWO METHODS TO MEASURE THE EFFECT OF PURCHASES ON WELL- BEING}

\subsection{THE TRADITIONAL EXPERIMENTAL METHOD}

The conventional method to measure the effect of experiential and material purchases on happiness is the laboratory experiment. The typical study design is one in which $50-200$ participants, who are university students, are randomly assigned into two groups. One of these groups is asked to think about their most recent experiential purchase that had cost at least $\$ 100-300$, while the other group is asked to think about their most recent material purchase. Next, they are asked to rate how happy this purchase made them or how it contributed to their happiness: e.g., "How much does this purchase contribute to your happiness in life?" or "When you think about this purchase, how happy does it make you?"4

\footnotetext{
3 Contrary to these findings, Thomas and Millar (2013) found little support for the mediating role of social relationships.

4 Of course there are some exceptions in which the researchers followed a slightly different method. Some studies followed the conventional procedure but used a more heterogeneous sample (Caprariello \& Reis, 2013; Carter \& Gilovich, 2012; Van Boven \& Gilovich, 2003). In these experiments, participants were recruited through the internet or a telephone survey, thus representing a more general population. Others performed "real-time" experiments (Nicolao,
} 
Although this procedure is widely used in the literature, it has certain limitations. First of all, the number of participants is often small and the samples are frequently homogeneous. Small sample sizes, and consequently low statistical power, weaken the reliability of the findings (Button et al., 2013; Ioannidis, 2005; Maxwell, 2004). Another concern is whether the results would remain the same if a different population were studied. Only a few studies have tried to answer this issue by using a more diverse sample.

The second limitation is that almost all of the experiments were conducted in the United States. It remains to be seen whether we would see the same effects in other countries or in other cultures. The vast majority of the published papers have analyzed the effects of purchase type on subjective well-being using an American population. As a result, the external validity of these studies is limited.

The third limitation results from the fact that materialistic individuals are often considered to be selfish and self-centered; materialism is frequently viewed as a negative personality trait (Van Boven et al., 2010). Because of this stigmatizing effect, participants may have tended to underrate (consciously or unconsciously) the satisfaction they obtained from material purchases. Therefore, although material objects may have made people as happy as experiences did, this was less likely to appear in the results because the participants did not want to be categorized as materialistic.

Finally, people were asked directly how happy the experiences or material objects made them; this may have been an unfamiliar question and thus produced biased results. It is probable that most individuals were not prepared to answer a question about how happy a new flat-screen television made them. There is evidence that thinking about happiness caused by past events results in an overestimation (due to focalism) of the actual feelings occurred during these events (Mitchell, Thompson, Peterson, \& Cronk, 1997; Wilson, Meyers, \& Gilbert, 2003; Wirtz, Kruger, Scollon, \& Diener, 2003). Therefore, assessing happiness using a direct question may have led to superficial and less reliable answers.

\subsection{OUR SURVEY METHOD}

To avoid the limitations of the typical procedure used, we followed a different study method. We did not perform an experiment; instead, we used survey data to examine the relationship between experiential/material expenditures and well-being. One of the main advantages of survey data is the large sample size, which provides a greater statistical power and thus reduces the potential reliability problems. Additionally, the socio-demographically 
heterogeneous respondents were representative of the population, thus the external validity (generalizability) of the results was high. Another important feature of our analysis is that our data came from Hungary; we were able to analyze the association between expenditures and subjective well-being outside of the USA.

Our databases contained a series of questions on expenditures and separate questions about life satisfaction in general; therefore, the participants were not directly asked about the effect of experiential purchases and material purchases on their well-being. This method also reduced the subjects' cognitive burden. By using a series of questions on expenditures and a distinct set of questions about life satisfaction, we could create an ex post connection between well-being and purchases and thus avoid the potential social desirability bias of responding as though one were not materialistic.

Our analysis was also novel because we did not expect a linear relationship between expenditures and satisfaction; we did not assume that every subsequent dollar spent on experiences or material goods had the same effect on satisfaction. In other words, we allowed "prior" spending to alter the effect of "later" purchases. This linear relationship was an implicit assumption of previous experimental analysis, as they did not examine how the effect of expenditures changed with a change in the amount spent on material goods or experiences. 5 In the studies below, we performed both linear and non-linear analyses. The non-linear analyses enabled us to test how the association between expenditures and wellbeing changed depending on the level of expenditure. We were also able to assess the differences in marginal effects (marginal utilities) of material and experiential spending.

\section{STUDY 1}

\subsection{DATA}

In Study 1, we used two pooled cross-sectional surveys from Hungary that were collected in 2005 and 2007 (TÁRKI Household Monitor 2005 and 2007). The TÁRKI Household Monitors contains data from randomly sampled households and covers approximately 7500 individuals. The individuals in the samples are representative of the Hungarian population aged 16 and over.

The surveys contained two global life satisfaction questions measured on an 11-point scale: "How satisfied are you with how your life has turned out so far?" and "All things considered, how satisfied are you with your life?" (o - extremely dissatisfied, 10 - extremely satisfied). We used the average score of the answers to these questions as the dependent

\footnotetext{
5 A recent exception is a paper by Quoidbach et al. (2015), which analyzed how previous travel experiences influenced the ability to savor a trip.
} 
variable. We then standardized this variable (subtracted the mean and divided by the standard deviation).

In these surveys, expenditures were measured at the household-level. One member of the household reported detailed information on the expenditures of the household. They estimated how much the household had spent on different types of purchases in the last month, the last 3 months, and the last 12 months. The recall periods depended on the type of expenditure. In general, longer reference periods were used for goods and services that were more expensive or were purchased irregularly. On the other hand, shorter reference periods were used for goods and services that were of less value or were purchased frequently or at regular intervals. Participants were asked about the amount that they had spent on 23 different expenditure categories: from food to internet subscription fees and medical expenses to holiday spending (for details see Table A1 in the Appendix). From these 23 categories, we calculated the household's equivalent yearly expenditures.

Next, we constructed two additional variables using the most typical experiential and material purchase categories. The first variable summed the equivalent yearly spending on entertainment, sport and holiday, and the second variable summed the yearly spending on clothing and electronics. ${ }^{6}$ Previous studies (discussed in Section 2) have shown that people consider these types of purchases to be the most typical example of the two types of purchases (experiential and material). Both indicators were divided by the total equivalent expenditures of the household, resulting in variables that measured experiential and material expenditures as the percentage of the total yearly spending.

For our analyses, we retained individuals who had valid data on expenditures and life satisfaction. In addition, individuals in the lowest and highest 0.5 percent of the equivalent monthly expenditures distribution were excluded from the analysis because their expenditures data were considered to be unreliable and most likely biased.7 The final sample size was 6039.

Table 1 provides descriptive statistics of the main variables. Respondents spent an average of 2.26 percent of their yearly expenditures on experiences (leisure, sport and holiday) and 4.78 percent on material goods (clothes and electronics).

\footnotetext{
${ }^{6}$ Equivalent spending was calculated by using the classic OECD scale.

7 As a robustness test, we checked how inclusion of these individuals alters the regression results. We found that the coefficients and the significance levels did not change considerably: the conclusions remained the same. The same is true for Study 2.
} 
Summary statistics of the main variables (TÁRKI Household Monitor)

\begin{tabular}{lccccc}
\hline \multicolumn{1}{c}{ Variable } & N & Mean & SD & Min & Max \\
\hline Life satisfaction & 6039 & 0 & 1 & -3.14 & 1.94 \\
Experiential expenditures (\%) & 6039 & 2.26 & 4.16 & 0 & 40.97 \\
Material expenditures (\%) & 6039 & 4.78 & 5.17 & 0 & 34.17 \\
$\begin{array}{l}\text { Equivalent yearly expenditures } \\
\text { (price adjusted 2005 HUF) }\end{array}$ & 6039 & 748977 & 392766 & 156000 & 2838880 \\
\hline
\end{tabular}

\subsection{ESTIMATION METHOD}

We analyzed the association between expenditures and satisfaction using the following equation:

$L S_{i}=\alpha+\beta_{1} \cdot \frac{E_{i}^{1-\rho_{1}}}{1-\rho_{1}}+\beta_{2} \cdot \frac{M_{i}^{1-\rho_{2}}}{1-\rho_{2}}+\mu^{\prime} \cdot X_{i}+\varepsilon_{i}$,

where $L S_{i}$ was the life satisfaction of individual $\mathrm{i} ; E_{i}$ and $M_{i}$ were the share of experiential and material expenditures in the individual i's household; $X_{i}$ was the vector of the control variables; and $\varepsilon_{i}$ was the usual error term. The control variables were the following: gender, age, age squared, equivalent income (in $\log$ form) ${ }^{8}$, equivalent expenditures (in log form), education, marital status, labor force status, subjective health status, Roma ethnicity, selfdefined social class, religiousness, household size, value of the house (in log form), domicile, region, and survey year. 9

In this equation, material and experiential expenditures had two parameters; the $\beta$ parameter indicated the sign of the association between expenditure and satisfaction, and the $\rho$ parameter showed how the association changed with the level of experiential/material expenditures. If $\rho>0$, then the marginal utility was decreasing. If $\rho=0$, the marginal utility was constant. If $\rho<0$, then the marginal utility was increasing. In other words, if $\rho$ was positive, then spending more money on experiences/material goods was associated with a lower increase in satisfaction at higher levels of expenditures. This allowed us to assess the association between expenditures and satisfaction at low levels of experiential/material expenditures and at high levels of experiential/material expenditures.

We estimated non-linear least squares regressions using weights that adjusted for the unequal inclusion probabilities. The standard error estimates were robust to heteroscedasticity and were clustered at the household level. Missing explanatory variables

\footnotetext{
${ }^{8}$ Income, expenditures and value of the house in the 2007 survey measured in Hungarian Forint (HUF) at the 2005 prices.

9 Table A2 in the Appendix provides descriptive statistics of the control variables
} 
(except the experiential, material and total expenditures variables) were addressed by including dummies for missing status.

\subsection{RESULTS}

Table 2 shows the regression results. In the first step, we present a linear model. In Column 1, the $\rho$ parameters were set to zero, thus a linear association was estimated between expenditures and life satisfaction. In this specification, both of the $\beta$ coefficients were positive and significant at the 1 percent level, indicating that spending more money both on experiences and material goods was associated with higher satisfaction levels. The estimation showed that one percentage point increase in the share of experiential expenditures was associated with a 0.014 unit increase in life satisfaction (measured in standard deviation), whereas the same increase in the share of material expenditures was associated with a 0.008 unit increase in satisfaction. However, the two coefficients did not differ statistically.

In Column 2, we estimated a non-linear model. Focusing on the $\rho$ parameters, we can see that $\rho_{1}$ was positive but statistically insignificant (0.163; $\mathrm{p}=0.598$ ), whereas $\rho_{2}$ was significantly greater than zero $(0.597 ; \mathrm{p}=0.013)$. This suggests that the relationship between experiential expenditures and life satisfaction was close to linear but that the marginal effect of material expenditures was decreasing. However, we could not reject the hypothesis of equal $\rho$ coefficients $(\mathrm{p}=0.270)$.

Because $\rho$ parameter for experiential expenditures was insignificant, we estimated an additional specification in which $\rho_{1}$ was set to zero. Column 3 shows these results. $\beta_{1}$ was estimated with more precision than in Column 2, which resulted in a highly significant parameter. The main conclusion remained unchanged; both experiential expenditures and material expenditures were associated with higher satisfaction levels, but the marginal effect was decreasing for material purchases. ${ }^{10}$

${ }^{10}$ It can be argued that a proportion of the spending on clothing should be taken into account as a basic need. Without correcting for this factor, the coefficient of material expenditures might be underestimated. In the Appendix (Table A3 and Table A5 for Study 1 and Study 2, respectively) we show models in which spending of 1000 HUF (measured in equivalent monthly expenditures) on clothing was considered to be the fulfillment of basic needs, and this amount was excluded from the material expenditures. These results did not differ considerably from the results presented here. 


\section{The association between experiential and material expenditures and subjective well-being (TÁRKI Household Monitor)}

\begin{tabular}{lcccc}
\hline & & $(1)$ & $(2)$ & $(3)$ \\
\hline Experiential expenditures (\%) & $\beta_{1}$ & $\begin{array}{c}0.014^{* * *} \\
(0.003)\end{array}$ & $\begin{array}{c}0.018^{*} \\
(0.010)\end{array}$ & $\begin{array}{c}0.014^{* * *} \\
(0.003)\end{array}$ \\
& $\rho_{1}$ & & $\begin{array}{c}0.163 \\
(0.310)\end{array}$ & \\
Material expenditures (\%) & $\beta_{2}$ & $\begin{array}{c}0.008^{* * *} \\
(0.003)\end{array}$ & $\begin{array}{c}0.021^{* * *} \\
(0.006)\end{array}$ & $\begin{array}{c}0.021^{* * *} \\
(0.006)\end{array}$ \\
& $\rho_{2}$ & & $\begin{array}{c}0.597^{* *} \\
(0.239)\end{array}$ & $\begin{array}{c}0.598^{* *} \\
(0.234)\end{array}$ \\
Controls & & Yes & Yes & Yes \\
\hline $\begin{array}{l}\text { Adjusted R } \\
\mathrm{N}\end{array}$ & & 0.351 & 0.351 & 0.351 \\
p-value on test of equal $\beta$ & & 6039 & 6039 & 6039 \\
coefficients & & 0.230 & - & - \\
p-value on test of equal $\rho$ & & - & 0.270 & - \\
coefficients & & & & \\
\hline
\end{tabular}

\footnotetext{
Dependent variable: Life satisfaction (standardized).

Robust standard errors adjusted for clustering by household are in parentheses.

Controls: gender, age, age squared, equivalent income (in log form), equivalent expenditures (in $\log$ form), education, marital status, labor force status, subjective health status, Roma ethnicity, self-defined social class, religiousness, household size, value of the house (in log form), domicile, region, and survey year.

Dummies are included for missing regressors (except for the expenditure variables).

${ }^{*} \mathrm{p}<0.10,{ }^{* *} \mathrm{p}<0.05,{ }^{* * *} \mathrm{p}<0.01$
}

The relationship between expenditures and life satisfaction was determined jointly by parameter $\rho$ and parameter $\beta$, therefore we should look at the graphs of the estimated marginal effects to better understand these associations. For this exercise, we used the $\beta$ and $\rho$ coefficients from Column 2 in Table 2 . We regarded these parameters as unbiased (but perhaps imprecise) estimates. Figure 1 depicts the estimated marginal utilities. On the horizontal axis, the percentage share of experiential and material expenditures is shown, and on the vertical axis, the estimated marginal utilities are depicted. We can conclude that spending more money on experiences was associated with a more or less constant increase in life satisfaction. On the other hand, spending more money on material goods was associated with a very low increase in life satisfaction at higher levels of material expenditures. 


\section{The marginal utility of experiential and material expenditures (TÁRKI Household Monitor)}
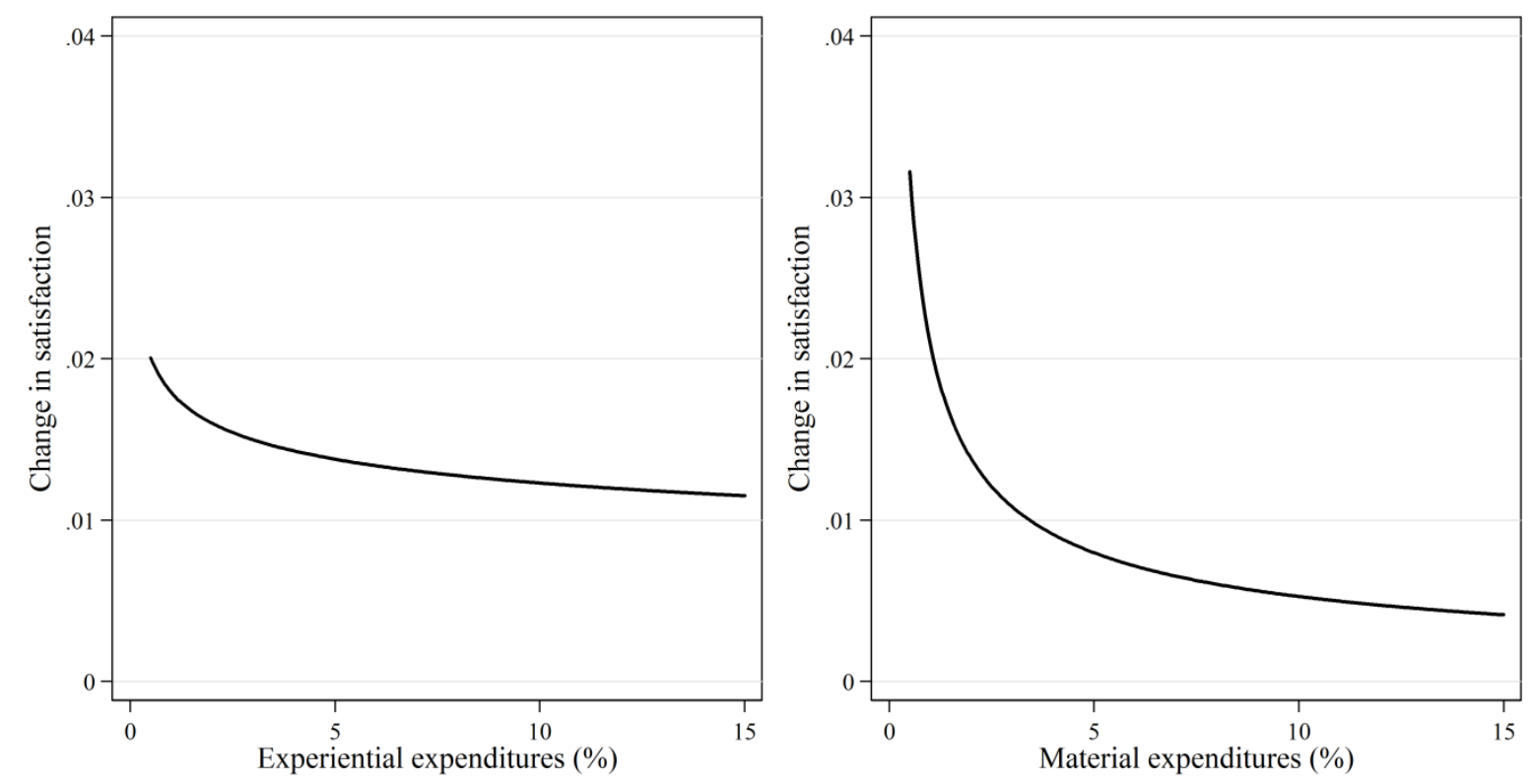

Another advantage of estimating non-linear associations was that it allowed us to calculate the optimal allocation of experiential and material expenditures to maximize the satisfaction of an individual. We considered the money an individual spent on experiences and material goods as a discretionary income that was only allowed to be spent on experiences or material goods. At optimal allocation, the marginal utilities (marginal effect) of the last unit of money spent on experiences and material goods are equal. Formally:

$$
\beta_{1} \cdot E_{i}^{-\rho_{1}}=\beta_{2} \cdot M_{i}^{-\rho_{2}}
$$

We calculated the optimal allocation for an average person who spends 7.04 percent of their total expenditures on experiences and material goods (see Table 1). We assumed that she could not spend more money on these expenditures, thus $E_{i}+M_{i}=7.04$. The $\beta$ and $\rho$ parameters were obtained from Column 2 in Table 2. The observed ratio between experiential and material expenditures for the average person was 1:2 (2.26 percent vs. 4.78 percent, respectively); however, the optimal ratio was calculated to be approximately 3:1. According to this calculation, a satisfaction-maximizing individual would spend 5.13 percent of her expenditures on experiences and 1.91 percent on material goods. This suggests that an average individual might slightly increase her well-being by reallocating her expenditures in favor of experiences. 


\section{STUDY 2}

\subsection{DATA}

In the second study, we analyzed the 2002 data from the nationally representative Hungarian Household Budget Survey (HHBS) of the Hungarian Central Statistical Office (HCSO). The main goal of this survey is to collect detailed information on household expenditures. In every wave (year), approximately 9000-10000 households participate in the survey. A third of the households in the sample are rotated each year, which means that, theoretically, households participate in the survey for three consecutive years.

In general, subjective well-being is not measured in the HHBS questionnaire, but in 2002, the adult members of the households who were participating in the HHBS for the third time in 2002 were asked about their life satisfaction in a supplementary questionnaire (as part of the yearly survey, see below). Altogether more than 3500 persons ${ }^{11}$ answered the following satisfaction question on a 5-point scale: "All things considered, how satisfied are you with how your life has turned out so far?” (1 - extremely dissatisfied, 5 - extremely satisfied). For analytical purposes, the standardized values of this life satisfaction question were used in the paper.

The expenditures were measured at the household-level. Every household kept an expenditure diary for a one-month period, and they recorded all of their purchases in that month. At the beginning of the next year (in Spring 2003 for the 2002 wave), this was followed by another survey concerning expenditures for the whole year. This survey provided information on the yearly purchases of the most important and significant expenditures categories and on the expensive or infrequently purchased goods and services.

We calculated aggregate equivalent yearly expenditure variables using the yearly expenditures data if available for a given type of expenditure (e.g., expenditures on laptops/desktops/etc. or spending on travel). In the absence of the yearly data, we used the diary records (e.g., expenditures on foods were only recorded in the expenditure diary). We used the most typical experiential/material purchases suggested by the literature to define households' expenditures on experiences and material goods. The variable of experiential expenditures was constructed as the yearly amount spent on travel, entertainment (theater, cinema, museum, sport), and food consumption in restaurants and other catering businesses. The variable of material expenditures was constructed as the yearly amount spent

\footnotetext{
${ }^{11}$ Because of attrition, around 2000 households remained in the survey for three consecutive years in the HHBS.
} 
on clothing, jewelry, artwork, and electronics. Both variables were divided by the total yearly expenditures to calculate the percentage of the total yearly spending.

Households with incomplete expenditure diaries were excluded from the analysis, as were the households that reported extremely high or extremely low expenditures in the month when they completed the diary. For our analysis, we retained individuals who had valid data on expenditures and life satisfaction. In addition, individuals in the lowest and highest 0.5 percent of the equivalent expenditures distribution were excluded from the analysis because their expenditures data were considered to be unreliable and likely biased. The final sample size was 3190.

Table 3 shows that the respondents spent, on average, 2.14 percent of their expenditures on experiences (travel, entertainment, restaurant meals) and 6.39 percent on material goods (clothing, electronics, jewelry, artwork).

Table 3

\section{Summary statistics of the main variables}

(Hungarian Household Budget Survey)

\begin{tabular}{lccccc}
\hline \multicolumn{1}{c}{ Variable } & N & Mean & SD & Min & Max \\
\hline Life satisfaction & 3190 & 0 & 1 & -1.67 & 2.22 \\
Experiential expenditures (\%) & 3190 & 2.14 & 4.11 & 0 & 35.32 \\
$\begin{array}{l}\text { Material expenditures (\%) } \\
\begin{array}{l}\text { Equivalent yearly expenditures } \\
\text { (HUF) }\end{array}\end{array}$ & 3190 & 6.39 & 4.96 & 0 & 31.54 \\
\hline
\end{tabular}

\subsection{ESTIMATION METHOD}

In Study 2, we estimated the same equation as in Study 1:

$$
L S_{i}=\alpha+\beta_{1} \cdot \frac{E_{i}^{1-\rho_{1}}}{1-\rho_{1}}+\beta_{2} \cdot \frac{M_{i}^{1-\rho_{2}}}{1-\rho_{2}}+\mu^{\prime} \cdot X_{i}+\varepsilon_{i}
$$

where $L S_{i}$ was the life satisfaction of individual $\mathrm{i} ; E_{i}$ and $M_{i}$ were the share of experiential and material expenditures; $X_{i}$ was the vector of control variables; and $\varepsilon_{i}$ was the error term. Control variables were the following: gender, age, age squared, equivalent expenditures (in $\log$ form), equivalent income (in log form), subjective income status, education, marital status, labor force status, frequency of inviting guests, household size, number of children in the household, value of the house (in log form), type of the house, regular medication, 
smoking, a sick individual in the household or one needing nursing, domicile, region, and diary month.12

Weights were used to adjust for the unequal inclusion probabilities. The standard error estimates were robust to heteroscedasticity and clustered at the household level. Missing explanatory variables (except the expenditures variables) were addressed by including dummies for missing status.

\subsection{RESULTS}

Table 4 summarizes the regression results of Study 2. Column 1 shows the linear estimates. Both experiential and material expenditures were positively related to life satisfaction, and the strengths of the associations were very similar. We found no evidence from the linear associations that experiences made people more satisfied. Column 2 shows the non-linear results. According to the $\rho$ parameters, the association between experiential expenditures and satisfaction was rather linear $\left(\rho_{1}=0.287, p=0.568\right)$, whereas the association between material expenditures and satisfaction was significantly decreasing $\left(\rho_{2}=0.605, p=0.041\right)$.

Table 4

\section{The association between experiential and material expenditures and subjective well-being (Hungarian Household Budget Survey)}

\begin{tabular}{|c|c|c|c|c|}
\hline & & (1) & (2) & (3) \\
\hline Experiential expenditures (\%) & $\beta_{1}$ & $\begin{array}{l}0.013^{* *} \\
(0.006)\end{array}$ & $\begin{array}{c}0.022 \\
(0.017)\end{array}$ & $\begin{array}{l}0.014^{* *} \\
(0.006)\end{array}$ \\
\hline \multirow{3}{*}{ Material expenditures (\%) } & $\rho_{1}$ & & $\begin{array}{c}0.287 \\
(0.502)\end{array}$ & \\
\hline & $\beta_{2}$ & $\begin{array}{l}0.014^{* *} \\
(0.006)\end{array}$ & $\begin{array}{l}0.044^{* *} \\
(0.021)\end{array}$ & $\begin{array}{l}0.043^{* *} \\
(0.021)\end{array}$ \\
\hline & $\rho_{2}$ & & $\begin{array}{l}0.605^{* *} \\
(0.296)\end{array}$ & $\begin{array}{l}0.599^{* *} \\
(0.299)\end{array}$ \\
\hline Controls & & Yes & Yes & Yes \\
\hline Adjusted $\mathrm{R}^{2}$ & & 0.241 & 0.241 & 0.241 \\
\hline $\mathrm{N}$ & & 3190 & 3190 & 3190 \\
\hline $\begin{array}{l}\mathrm{p} \text {-value on test of equal } \beta \\
\text { coefficients }\end{array}$ & & 0.925 & - & - \\
\hline $\begin{array}{l}\text { p-value on test of equal } \rho \\
\text { coefficients }\end{array}$ & & - & 0.571 & - \\
\hline
\end{tabular}

Dependent variable: Life satisfaction (standardized).

Robust standard errors adjusted for clustering by household are in parentheses.

Controls: gender, age, age squared, equivalent expenditures (in log form), equivalent

${ }^{12}$ Table A4 in the Appendix provides the descriptive statistics of the control variables. 
income (in log form), feeling about household's income, education, marital status, labor force status, frequency of inviting guests, household size, number of children in the household, value of the house (in log form), type of the house, regular medication, smoking, a sick individual in the household or one needing nursing, domicile, region, and diary month.

Dummies are included for missing regressors (except for the expenditure variables).

${ }^{*} \mathrm{p}<0.10,{ }^{* *} \mathrm{p}<0.05,{ }^{* * *} \mathrm{p}<0.01$

However, we could not reject the hypothesis of equal $\rho$ coefficients $(\mathrm{p}=0.571)$. In the nonlinear specification, the $\beta_{1}$ coefficient was also insignificant, but this result was primarily because the expenditures variables had two parameters and their estimations were imprecise. Column 3 shows that setting the $\rho_{1}$ parameter to zero resulted in a significantly positive $\beta_{1}$ coefficient.

Based on the $\beta$ and $\rho$ coefficients from Column 2 in Table 4, we depict the marginal utility of experiential and material expenditures on life satisfaction in Figure 2. We can see that experiential and material purchases seemed to be quite similarly associated with life satisfaction, even at higher levels of expenditures. At lower levels of expenditures, material purchases appeared to have a higher marginal effect.

Figure 2

\section{The marginal utility of experiential and material expenditures (Hungarian Household Budget Survey)}
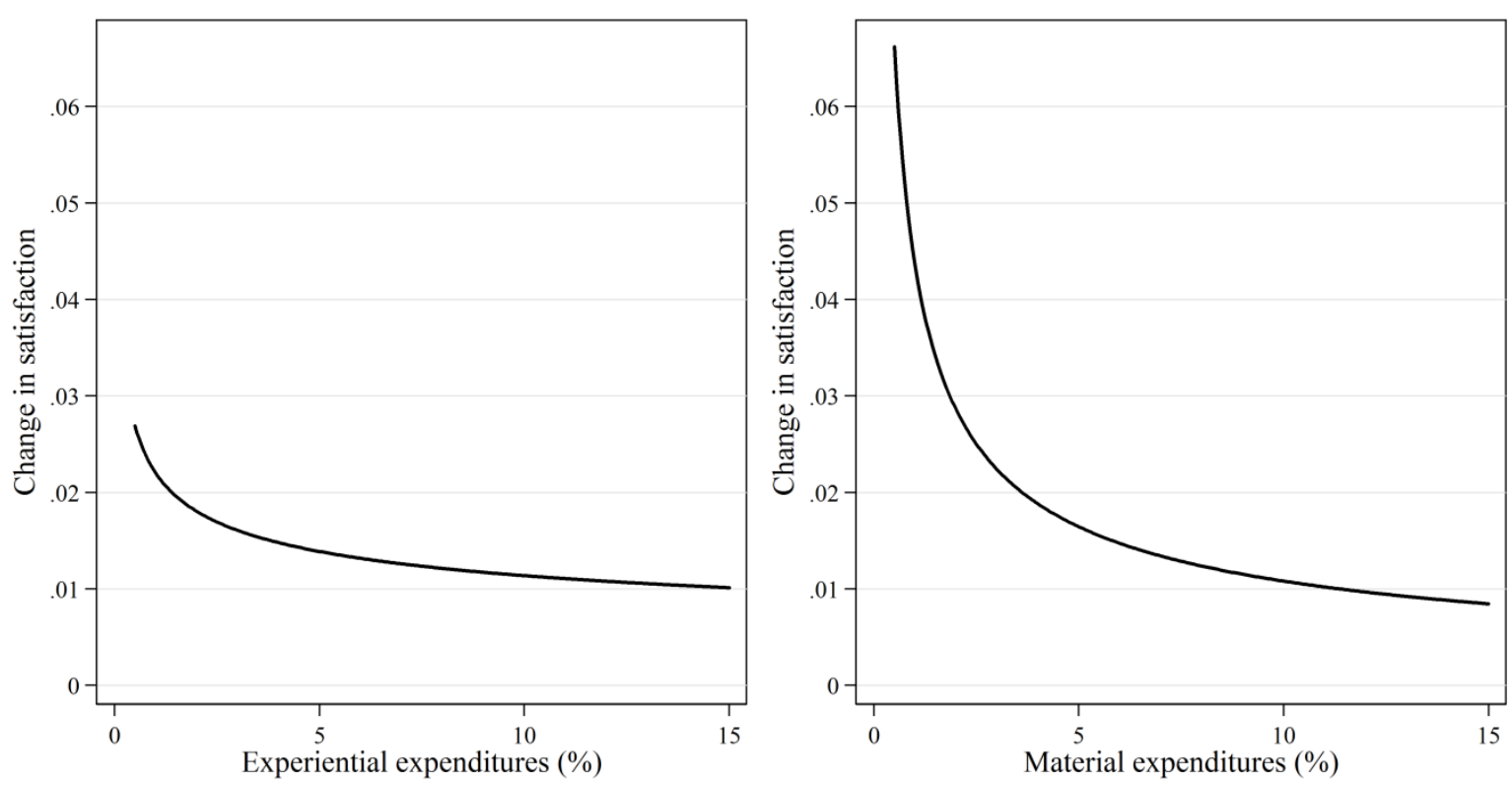

As in Study 1, in Study 2 we also calculated the optimal allocation of experiential and material expenditures (based on the results of Column 2 in Table 4) for an average person who spends 8.53 percent of her total expenditures on experiences and material goods (2.14 
percent and 6.39 percent, respectively). This exercise showed that the optimal ratio of experiential to material expenditures was approximately 1:1.5 (3.15 percent / 5.37 percent) instead of the observed 1:3 ratio (2.14 percent / 6.39 percent). This suggests that to maximize life satisfaction, an average person should allocate an additional 1 percent of her money to buying experiences instead of material objects.

\section{DISCUSSION}

The present research found limited evidence on the greater hedonic return of buying experiences compered to buying material goods. The linear model in Study 1 showed that spending on experiences was associated slightly more (but not statistically) with life satisfaction than spending on material goods, but in Study 2, we found no real differences between the effects of material and experiential expenditures on satisfaction. The non-linear estimates suggested that the main distinction between experiential and material expenditures was that the marginal utility of experiences was linear, whereas the marginal utility of material goods was decreasing. This means that every additional unit of money spent on experiences had the same effect on life satisfaction, while spending more money on material goods was associated with a very low increase in life satisfaction at higher levels of material expenditures.

Our results did not support previous findings that claimed that experiential purchases rather than material purchases made people happier. The different results might be explained by the different methodology used (see Section 3). First, we used a survey approach - instead of an experimental one - in which the questions on expenditures and life satisfaction were not explicitly linked. This enabled us to reduce the potential social desirability bias in responding to direct questions. As society may treat materialism as a negative personality trait, the respondents may have underreported the satisfaction they received from material purchases in the experimental setting. Furthermore, because the stigma surrounding materialism would not influence the reported effects of experiential purchases, the difference between the effect of experiences and material objects may have been overestimated in previous studies. Second, we analyzed heterogeneous and nationally representative samples from Hungary, whereas most of the previous papers have been conducted with US university students.

One of the main contributions of the present research is the calculation of the optimal allocation of experiential and material expenditures to maximize life satisfaction. Performing non-linear estimates, we showed that the observed ratio of experiential to material expenditures was not optimal, suggesting that a reallocation of these expenditures might increase individual well-being. The primary implication of our study - which is similar to previous studies despite the differences mentioned above - is that people should shift their 
expenditures toward experiences to maximize their satisfaction. This change can be influenced and encouraged by governmental tax policies as well. A reduced value added tax on experiences could result in a growing demand for and consumption of experiences, and the decreasing tax revenue could be financed by levying higher taxes on typical material purchases. This type of tax change could increase the well-being of the society. Spending more on experiences and less on material goods does not require additional disposable income, meaning that even less wealthy individuals can increase their subjective well-being without unbearable costs. However, we note that these results are only indicative; calculating the exact optimal ratio between experiential and material expenditures requires more extensive research.

We stress that the existing experimental and survey studies provide an incomplete picture of the effect of experiential and material purchases on subjective well-being. Both types of studies measure the effect of consumption at a particular point in time, usually weeks or months after the purchase. However, purchases can make people happy at the time of purchase as well as after several days, weeks, months, or even years. Remembering an experience or re-using the purchased item can provide extra satisfaction. This implies that in an ideal experiment, we would measure the effect of a purchase on well-being not only at a particular moment but also over time: from the time of buying $(t=0)$ to the end of a longer period $(t=T)$. In such an experiment, we could measure the total hedonic effect of a purchase, which is the sum of the momentary well-being (St) measured continuously over time:

$$
S=\int_{t=0}^{T} S_{t} d t
$$

This type of experiment could use techniques such as the Experience Sampling Method (ESM) to measure subjects' well-being. Because the ESM collects information on the subjective experiences of individuals in real time using an electronic device (Csikszentmihalyi \& Larson, 1987; Csikszentmihalyi, Larson, \& Prescott, 1977), it can provide the necessary data to measure the total effect of the purchases on well-being over time. This type of approach may lead to a different result from that of the existing literature, which mainly focuses on the long-term effects of experiential and material purchases.

\section{LIMITATIONS}

We have already discussed the drawbacks of the usual experimental method; however, our analysis had its own limitations as well. First, unlike experiments, our method was not able to establish a causal relationship between expenditures and well-being. We presented here only associations and correlations. There are several unmeasured factors that might have influenced both expenditures and life satisfaction; however, we did use a number of control variables to limit this omitted variable bias. 
The second limitation is that the expenditures were measured at the household level, while satisfaction was measured at the individual level. It is reasonable to suppose that the material and experiential expenditures were not equally divided between the members of the households, which means that the individual consumption of experiences and material goods were measured with bias. To obtain a more precise estimation we would need datasets that measure detailed individual expenditures instead of household expenditures.

Thirdly, some of the reported spending may be inaccurate. Recalling the exact amount that was spent on holidays in the last year or on sport in the last three months could be biased. This inaccuracy might be more pronounced with longer reference periods. In Study 2, the expenditure diary may have addressed this issue; however, some expenditures are clustered in particular periods of the year, and we would thus need a longer time span than one month to measure these expenditures using the diary method. To obtain data on each type of expenditure, we had to use the retrospective measures from the yearly survey despite the possible inaccuracies.

\section{CONCLUSION}

In this paper, we used large-scale representative survey databases from Hungary to analyze whether people who spend money on experiences rather than on material goods were more satisfied. We estimated the association between expenditures and life satisfaction using linear and non-linear models. The primary addition of our analysis was that we examined the effect of actual purchase decisions on well-being instead of using mentally recalled purchases. We did not ask people directly how happy experiences or material objects made them. We were thus able to draw an ex post connection between well-being and different types of expenditures, and we were able to avoid the limitations of the usual experimental methodology. Although both experiential and material expenditures were positively associated with life satisfaction, the evidence supporting the greater return from experiential purchases was limited. The main difference between experiential purchases and material purchases was that the marginal utility of the experiential purchases appeared to be linear, whereas material purchases had a decreasing marginal utility. In addition, despite the limited difference between the effects of experiential and material purchases, we showed that a reallocation of an average person's expenditures (spending more on experiences and less on material goods) might increase individual well-being.

The presented findings do not indicate that the previous results from the literature are false positives; rather, they suggest that more empirical analyses are needed. Specifically, we emphasize the importance of exploring the distortion effects of the different methods used to measure the relationship between expenditures and subjective well-being, analyzing more 
diverse samples from different countries of the world, and measuring the overall effects of consumption from the time of purchase to the end of a longer period. 


\section{REFERENCES}

Alpizar, F., Carlsson, F., \& Johansson-Stenman, O. (2005). How much do we care about absolute versus relative income and consumption? Journal of Economic Behavior \& Organization, 56(3), 405-421. http://doi.org/10.1016/j.jebo.2002.10.007

Button, K. S., Ioannidis, J. P. A., Mokrysz, C., Nosek, B. A., Flint, J., Robinson, E. S. J., \& Munafò, M. R. (2013). Power failure: why small sample size undermines the reliability of neuroscience. Nature Reviews Neuroscience, 14(5), 365-376. http://doi.org/10.1038/nrn3475

Caprariello, P. A., \& Reis, H. T. (2010). To do with others or to have (or to do alone)? The value of experiences over material possessions depends on the involvement of others. Advances in Consumer Research, 37, 762-763.

Caprariello, P. A., \& Reis, H. T. (2013). To do, to have, or to share? Valuing experiences over material possessions depends on the involvement of others. Journal of

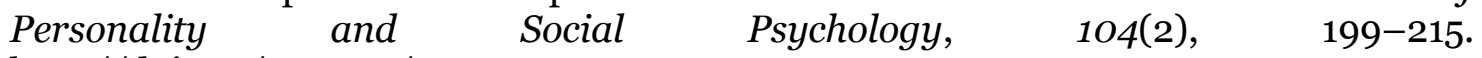
http://doi.org/10.1037/a0030953

Carlsson, F., Johansson-Stenman, O., \& Martinsson, P. (2007). Do You Enjoy Having More than Others? Survey Evidence of Positional Goods. Economica, 74(296), 586598. http://doi.org/10.1111/j.1468-0335.2006.00571.x

Carter, T. J., \& Gilovich, T. (2010). The relative relativity of material and experiential purchases. Journal of Personality and Social Psychology, 98(1), 146-159. http://doi.org/10.1037/aoo17145

Carter, T. J., \& Gilovich, T. (2012). I am what I do, not what I have: the differential centrality of experiential and material purchases to the self. Journal of Personality and Social Psychology, 102(6), 1304-1317. http://doi.org/10.1037/a0027407

Csikszentmihalyi, M., \& Larson, R. (1987). Validity and reliability of the experiencesampling method. Journal of Nervous and Mental Disease, 175(9), 526-536. http://doi.org/10.1097/00005053-198709000-00004

Csikszentmihalyi, M., Larson, R., \& Prescott, S. (1977). The ecology of adolescent activity and experience. Journal of Youth and Adolescence, 6(3), 281-294. http://doi.org/10.1007/BF02138940

Demır, M., \& Weitekamp, L. A. (2007). I am so Happy 'Cause Today I Found My Friend: Friendship and Personality as Predictors of Happiness. Journal of Happiness Studies, 8(2), 181-211. http://doi.org/10.1007/s10902-006-9012-7

Dolan, P., Peasgood, T., \& White, M. (2008). Do we really know what makes us happy? A review of the economic literature on the factors associated with subjective well-being. Journal of Economic Psychology, 29(1), 94-122. http://doi.org/10.1016/j.joep.2007.09.001

Dunn, E. W., Gilbert, D. T., \& Wilson, T. D. (2011). If money doesn't make you happy, then you probably aren't spending it right. Journal of Consumer Psychology, 21(2), 115125. http://doi.org/10.1016/j.jcps.2011.02.002

Dunn, E. W., \& Norton, M. (2013). Happy Money: The New Science of Smarter Spending. London: Oneworld.

Easterlin, R. A. (1974). Does economic growth improve the human lot? Some empirical evidence. In P. A. David \& M. W. Reder (Eds.), Nations and Households in Economic Growth (pp. 89-125). New York: Academic Press.

Frank, R. H. (2005). Positional Externalities Cause Large and Preventable Welfare Losses. American Economic Review, 95(2), 137-141. http://doi.org/10.1257/000282805774670392 
Frijters, P., Haisken-DeNew, J. P., \& Shields, M. A. (2004). Money does matter! Evidence from increasing real income and life satisfaction in East Germany following reunification. American Economic Review, 94(3), 730-740. http://doi.org/10.1257/0002828041464551

Gilovich, T., \& Kumar, A. (2015). We'll Always Have Paris: The Hedonic Payoff from Experiential and Material Investments. In J. M. O. and M. P. Zanna (Ed.), Advances in Experimental Social Psychology (Vol. 51, pp. 147-187). Academic Press. Retrieved from http://www.sciencedirect.com/science/article/pii/So065260114000057

Guevarra, D. A., \& Howell, R. T. (2015). To have in order to do: Exploring the effects of consuming experiential products on well-being. Journal of Consumer Psychology, 25(1), 28-41. http://doi.org/10.1016/j.jcps.2014.06.006

Hajdu, T., \& Hajdu, G. (2014). Income and Subjective Well-Being: How Important is the Methodology? Hungarian Statistical Review, 92(Spec. No. 18), 110-128.

Helliwell, J. F., \& Putnam, R. D. (2004). The social context of well-being. Philosophical Transactions of the Royal Society B, 359(1449), 1435-1446. http://doi.org/10.1098/rstb.2004.1522

Howell, R. T., \& Hill, G. (2009). The mediators of experiential purchases: Determining the impact of psychological needs satisfaction and social comparison. The Journal of Positive Psychology, 4(6), 511-522. http://doi.org/10.1080/17439760903270993

Ioannidis, J. P. A. (2005). Why Most Published Research Findings Are False. PLoS Med, 2(8), e124. http://doi.org/10.1371/journal.pmed.0020124

Kahneman, D., \& Deaton, A. (2010). High income improves evaluation of life but not emotional well-being. Proceedings of the National Academy of Sciences, 107(38), 16489-16493. http://doi.org/10.1073/pnas.1011492107

Kahneman, D., Krueger, A. B., Schkade, D., Schwarz, N., \& Stone, A. A. (2006). Would You Be Happier If You Were Richer? A Focusing Illusion. Science, 312(5782), 1908-1910. http://doi.org/10.1126/science.1129688

Kumar, A., \& Gilovich, T. (2015). Some “Thing” to Talk About? Differential Story Utility From Experiential and Material Purchases. Personality and Social Psychology Bulletin. http://doi.org/10.1177/0146167215594591

Kushlev, K., Dunn, E. W., \& Lucas, R. E. (2015). Higher Income Is Associated With Less Daily Sadness but not More Daily Happiness. Social Psychological and Personality Science, 6(5), 483-489. http://doi.org/10.1177/1948550614568161

Layard, R., Mayraz, G., \& Nickell, S. J. (2008). The marginal utility of income. Journal of Public Economics, 92(8-9), 1846-1857. http://doi.org/10.1016/j.jpubeco.2008.01.007

Maxwell, S. E. (2004). The persistence of underpowered studies in psychological research: causes, consequences, and remedies. Psychological Methods, 9(2), 147-163. http://doi.org/10.1037/1082-989X.9.2.147

Millar, M., \& Thomas, R. (2009). Discretionary activity and happiness: The role of materialism. Journal of Research in Personality, 43(4), 699-702. http://doi.org/10.1016/j.jrp.2009.03.012

Mitchell, T. R., Thompson, L., Peterson, E., \& Cronk, R. (1997). Temporal Adjustments in the Evaluation of Events: The "Rosy View." Journal of Experimental Social Psychology, 33(4), 421-448. http://doi.org/10.1006/jesp.1997.1333

Nicolao, L., Irwin, J. R., \& Goodman, J. K. (2009). Happiness for Sale: Do Experiential Purchases Make Consumers Happier than Material Purchases? Journal of Consumer Research, 36(2), 188-198. http://doi.org/10.1086/597049 
Quoidbach, J., Dunn, E. W., Hansenne, M., \& Bustin, G. (2015). The Price of Abundance How a Wealth of Experiences Impoverishes Savoring. Personality and Social Psychology Bulletin, 41(3), 393-404. http://doi.org/10.1177/0146167214566189

Rosenzweig, E., \& Gilovich, T. (2012). Buyer's remorse or missed opportunity? Differential regrets for material and experiential purchases. Journal of Personality and Social Psychology, 102(2), 215-23. http://doi.org/10.1037/a0024999

Solnick, S. J., \& Hemenway, D. (1998). Is more always better?: A survey on positional concerns. Journal of Economic Behavior \& Organization, 37(3), 373-383. http://doi.org/10.1016/So167-2681(98)00089-4

Solnick, S. J., \& Hemenway, D. (2005). Are Positional Concerns Stronger in Some Domains than in Others? American Economic Review, 95(2), 147-151. http://doi.org/10.1257/000282805774669925

Stevenson, B., \& Wolfers, J. (2008). Economic growth and subjective well-being: Reassessing the Easterlin paradox. Brookings Papers on Economic Activity, 2008(1), 1-87. http://doi.org/10.1353/eca.0.0001

Stevenson, B., \& Wolfers, J. (2013). Subjective Well-Being and Income: Is There Any Evidence of Satiation? American Economic Review, 103(3), 598-604. http://doi.org/10.1257/aer.103.3.598

Thomas, R., \& Millar, M. (2013). The Effects of Material and Experiential Discretionary Purchases on Consumer Happiness: Moderators and Mediators. The Journal of Psychology, 147(4), 345-356. http://doi.org/10.1080/o0223980.2012.694378

Van Boven, L. (2005). Experientialism, materialism, and the pursuit of happiness. Review of General Psychology, 9(2), 132-142. http://doi.org/10.1037/1089-2680.9.2.132

Van Boven, L., Campbell, M. C., \& Gilovich, T. (2010). Stigmatizing materialism: on stereotypes and impressions of materialistic and experiential pursuits. Personality and Social Psychology Bulletin, 36(4), 551-63. http://doi.org/10.1177/0146167210362790

Van Boven, L., \& Gilovich, T. (2003). To Do or to Have? That is the question. Journal of Personality and Social Psychology, 85(6), 1193-1202. http://doi.org/10.1037/00223514.85.6.1193

Wilson, T. D., Meyers, J., \& Gilbert, D. T. (2003). "How Happy Was I, Anyway?” A Retrospective Impact Bias. Social Cognition, 21(6), 421-446. http://doi.org/10.1521/soco.21.6.421.28688

Wirtz, D., Kruger, J., Scollon, C. N., \& Diener, E. (2003). What to Do on Spring Break? The Role of Predicted, On-Line, and Remembered Experience in Future Choice. Psychological Science, 14(5), 520-524. http://doi.org/10.1111/1467-9280.03455 
Table A1

Questions on expenditures in the TÁRKI Household Monitor surveys (Study 1)

\begin{tabular}{|c|c|c|}
\hline \multicolumn{3}{|c|}{ How much did you spend } \\
\hline in the last month on... & in the last 3 months on.. & in the last 12 months on... \\
\hline 1) Food & 1) Clothing & 1) Flat equipment articles \\
\hline $\begin{array}{l}\text { 2) Consumer goods (cigarette, } \\
\text { alcohol) }\end{array}$ & $\begin{array}{l}\text { 2) Health-related expenses } \\
\text { (doctor, medicine, etc.) }\end{array}$ & 2) Holiday spending \\
\hline $\begin{array}{l}\text { 3) Transportation (petrol, single } \\
\text { ticket, pass) }\end{array}$ & 3) Toiletries, cosmetics & $\begin{array}{l}\text { 3) Maintenance and repair of } \\
\text { dwelling }\end{array}$ \\
\hline 4) Home help, babysitter & $\begin{array}{l}\text { 4) Cleaning materials } \\
\text { (detergents, washing-up liquid, } \\
\text { etc.) }\end{array}$ & 4) Electronics (durable) \\
\hline 5) Telephone bills & 5) Culture, education, tutoring & 5) Maintenance for children \\
\hline 6) TV subscription fees & 6) Entertainment & $\begin{array}{l}\text { 6) Money transfer to other } \\
\text { households }\end{array}$ \\
\hline 7) Internet subscription fees & 7) Sports & 7) Property tax \\
\hline $\begin{array}{l}\text { 8) Housing expenses (rent, } \\
\text { heating, gas, electricity, garbage } \\
\text { removal, etc.) }\end{array}$ & $\begin{array}{l}\text { 8) Hairdressing, beauty } \\
\text { treatment }\end{array}$ & \\
\hline
\end{tabular}


Table A2

Descriptive statistics, TÁRKI Household Monitor surveys (Study 1)

\begin{tabular}{|c|c|c|c|c|c|}
\hline Variable & $\mathbf{N}$ & Mean & SD & Min & Max \\
\hline Life satisfaction & 6039 & 0.00 & 1.00 & -3.14 & 1.94 \\
\hline Experiential expenditures (\%) & 6039 & 2.26 & 4.16 & o & 40.97 \\
\hline Material expenditures (\%) & 6039 & 4.78 & 5.17 & o & 34.17 \\
\hline $\begin{array}{l}\text { Equivalent yearly expenditures } \\
\text { (price adjusted } 2005 \text { HUF) }\end{array}$ & 6039 & 748977 & 392766 & 156000 & 2838880 \\
\hline Female & 6039 & 0.53 & 0.50 & o & 1 \\
\hline Age & 6029 & 46.12 & 18.52 & 16 & 96 \\
\hline Education: primary or less & 6039 & 0.30 & 0.46 & o & 1 \\
\hline $\begin{array}{l}\text { Education: vocational training } \\
\text { school }\end{array}$ & 6039 & 0.30 & 0.46 & o & 1 \\
\hline Education: high school & 6039 & 0.27 & 0.45 & o & 1 \\
\hline Education: tertiary & 6039 & 0.12 & 0.33 & o & 1 \\
\hline Education: missing & 6039 & 0.00 & 0.01 & o & 1 \\
\hline Marital status: single & 6039 & 0.22 & 0.41 & o & 1 \\
\hline $\begin{array}{l}\text { Marital status: married or living } \\
\text { with partner }\end{array}$ & 6039 & 0.59 & 0.49 & o & 1 \\
\hline Marital status: divorced & 6039 & 0.08 & 0.27 & o & 1 \\
\hline Marital status: widowed & 6039 & 0.11 & 0.31 & o & 1 \\
\hline Marital status: missing & 6039 & 0.00 & 0.03 & o & 1 \\
\hline Labor force status: employed & 6039 & 0.40 & 0.49 & o & 1 \\
\hline Labor force status: self-employed & 6039 & 0.04 & 0.20 & o & 1 \\
\hline $\begin{array}{l}\text { Labor force status: on maternity } \\
\text { leave }\end{array}$ & 6039 & 0.05 & 0.21 & o & 1 \\
\hline Labor force status: unemployed & 6039 & 0.06 & 0.24 & o & 1 \\
\hline Labor force status: retired & 6039 & 0.33 & 0.47 & o & 1 \\
\hline Labor force status: student & 6039 & 0.09 & 0.28 & o & 1 \\
\hline Labor force status: other inactive & 6039 & 0.03 & 0.17 & o & 1 \\
\hline Labor force status: missing & 6039 & 0.00 & 0.04 & $\mathrm{O}$ & 1 \\
\hline Health: bad & 6039 & 0.11 & 0.31 & o & 1 \\
\hline Health: changing, not satisfactory & 6039 & 0.19 & 0.39 & o & 1 \\
\hline $\begin{array}{l}\text { Health: changing, but more good } \\
\text { than bad }\end{array}$ & 6039 & 0.34 & 0.47 & o & 1 \\
\hline Health: good & 6039 & 0.36 & 0.48 & o & 1 \\
\hline Health: missing & 6039 & 0.00 & 0.02 & o & 1 \\
\hline Ethnicity: Roma & 6039 & 0.05 & 0.21 & $\mathrm{O}$ & 1 \\
\hline Ethnicity: missing & 6039 & 0.03 & 0.17 & o & 1 \\
\hline $\begin{array}{l}\text { Equivalent income (price adjusted } \\
2005 \text { HUF) }\end{array}$ & 6038 & 86466 & 53768 & 5941 & 923847 \\
\hline $\begin{array}{l}\text { Value of the house (price adjusted } \\
2005 \text { HUF) }\end{array}$ & 5225 & 11300000 & 8356126 & 100000 & 90000000 \\
\hline
\end{tabular}




\begin{tabular}{|c|c|c|c|c|c|}
\hline Household size & 6039 & 3.11 & 1.43 & 1 & 9 \\
\hline Domicile: Budapest & 6039 & 0.17 & 0.38 & $\mathrm{O}$ & 1 \\
\hline Domicile: city & 6039 & 0.50 & 0.50 & $\mathrm{O}$ & 1 \\
\hline Domicile: village & 6039 & 0.33 & 0.47 & $\mathrm{O}$ & 1 \\
\hline Religion: not religious & 6039 & 0.29 & 0.45 & o & 1 \\
\hline Religion: do not know & 6039 & 0.05 & 0.21 & O & 1 \\
\hline Religion: religious & 6039 & 0.54 & 0.50 & $\mathrm{O}$ & 1 \\
\hline Religion: religious in her own way & 6039 & 0.12 & 0.32 & o & 1 \\
\hline Religion: missing & 6039 & 0.01 & 0.08 & $\mathrm{O}$ & 1 \\
\hline Social class: upper class & 6039 & 0.00 & 0.02 & $\mathrm{O}$ & 1 \\
\hline Social class: upper middle class & 6039 & 0.02 & 0.14 & $\mathrm{O}$ & 1 \\
\hline Social class: middle class & 6039 & 0.32 & 0.47 & 0 & 1 \\
\hline Social class: lower middle class & 6039 & 0.25 & 0.43 & $\mathrm{O}$ & 1 \\
\hline Social class: working class & 6039 & 0.32 & 0.46 & $\mathrm{O}$ & 1 \\
\hline Social class: lower class & 6039 & 0.08 & 0.28 & $\mathrm{O}$ & 1 \\
\hline Social class: missing & 6039 & 0.01 & 0.12 & o & 1 \\
\hline Region: Central Hungary & 6039 & 0.25 & 0.43 & $\mathrm{O}$ & 1 \\
\hline Region: Central Transdanubia & 6039 & 0.09 & 0.29 & $\mathrm{O}$ & 1 \\
\hline Region: Western Transdanubia & 6039 & 0.11 & 0.31 & O & 1 \\
\hline Region: Southern Transdanubia & 6039 & 0.11 & 0.31 & o & 1 \\
\hline Region: Northern Hungary & 6039 & 0.14 & 0.34 & $\mathrm{o}$ & 1 \\
\hline Region: Northern Great Plain & 6039 & 0.17 & 0.38 & o & 1 \\
\hline Region: Southern Great Plain & 6039 & 0.13 & 0.33 & O & 1 \\
\hline Survey year: 2007 & 6039 & 0.47 & 0.50 & $\mathrm{O}$ & 1 \\
\hline
\end{tabular}


The association between experiential and material expenditures and subjective well-being (TÁRKI Household Monitor) - Adjusted to consider the spending of 1000 HUF (measured in equivalent monthly expenditures) on clothing as a basic need

\begin{tabular}{lcccc}
\hline & & $(1)$ & $(2)$ & $(3)$ \\
\hline Experiential expenditures (\%) & $\beta_{1}$ & $\begin{array}{c}0.014^{* * *} \\
(0.003)\end{array}$ & $\begin{array}{c}0.018^{*} \\
(0.010)\end{array}$ & $\begin{array}{c}0.014^{* * *} \\
(0.003)\end{array}$ \\
& $\rho_{1}$ & & 0.170 \\
$(0.305)$ & \\
Material expenditures (\%) & $\beta_{2}$ & $\begin{array}{c}0.008^{* *} \\
(0.003)\end{array}$ & $\begin{array}{c}0.012 \\
(0.013)\end{array}$ & $\begin{array}{c}(0.013 \\
(0.012)\end{array}$ \\
& $\rho_{2}$ & & $0.863^{* * *}$ & $0.856^{* * *}$ \\
Controls & & & $(0.179)$ & $(0.176)$ \\
\hline Adjusted R & & yes & yes & yes \\
N & & 0.350 & 0.351 & 0.351 \\
p-value on test of equal $\beta$ & & 6039 & 6039 & 6039 \\
coefficients & & 0.188 & - & - \\
p-value on test of equal $\rho$ & & & & - \\
coefficients & & - & 0.046 & - \\
\hline
\end{tabular}

Dependent variable: Life satisfaction (standardized).

Robust standard errors adjusted for clustering by household are in parentheses.

Controls: gender, age, age squared, equivalent income (in log form), equivalent expenditures (in $\log$ form), education, marital status, labor force status, subjective health status, Roma ethnicity, self-defined social class, religiousness, household size, value of the house (in log form), domicile, region, and survey year.

Dummies are included for missing regressors (except for the expenditure variables).

${ }^{*} \mathrm{p}<0.10,{ }^{* *} \mathrm{p}<0.05,{ }^{* * *} \mathrm{p}<0.01$ 
Table A4

Descriptive statistics, Hungarian Household Budget Survey (Study 2)

\begin{tabular}{|c|c|c|c|c|c|}
\hline Variable & $\mathbf{N}$ & Mean & SD & Min & Max \\
\hline Life satisfaction & 3190 & 0.00 & 1.00 & -1.67 & 2.22 \\
\hline Experiential expenditures (\%) & 3190 & 2.14 & 4.11 & o & $35 \cdot 32$ \\
\hline Material expenditures (\%) & 3190 & 6.39 & 4.96 & o & 31.54 \\
\hline $\begin{array}{l}\text { Equivalent yearly expenditures } \\
\text { (price adjusted 2005 HUF) }\end{array}$ & 3190 & 626903 & 293312 & 186936 & 2224240 \\
\hline Female & 3190 & 0.54 & 0.50 & o & 1 \\
\hline Age & 3190 & 47.72 & 17.63 & 18 & 97 \\
\hline Education: less than primary & 3190 & 0.07 & 0.26 & $\mathrm{O}$ & 1 \\
\hline Education: primary & 3190 & 0.26 & 0.44 & o & 1 \\
\hline $\begin{array}{l}\text { Education: vocational training } \\
\text { school }\end{array}$ & 3190 & 0.27 & 0.44 & o & 1 \\
\hline Education: high school & 3190 & 0.28 & 0.45 & o & 1 \\
\hline Education: tertiary & 3190 & 0.11 & 0.31 & $\mathrm{O}$ & 1 \\
\hline Marital status: single & 3190 & 0.20 & 0.40 & $\mathrm{O}$ & 1 \\
\hline $\begin{array}{l}\text { Marital status: married or living } \\
\text { with partner }\end{array}$ & 3190 & 0.59 & 0.49 & o & 1 \\
\hline Marital status: divorced & 3190 & 0.14 & 0.35 & $\mathrm{O}$ & 1 \\
\hline Marital status: widowed & 3190 & 0.07 & 0.26 & o & 1 \\
\hline Labor force status: employed & 3190 & 0.38 & 0.49 & o & 1 \\
\hline Labor force status: self-employed & 3190 & 0.05 & 0.22 & o & 1 \\
\hline Labor force status: unemployed & 3190 & 0.08 & 0.26 & $\mathrm{O}$ & 1 \\
\hline Labor force status: retired & 3190 & 0.36 & 0.48 & o & 1 \\
\hline Labor force status: student & 3190 & 0.04 & 0.21 & o & 1 \\
\hline $\begin{array}{l}\text { Labor force status: on maternity } \\
\text { leave }\end{array}$ & 3190 & 0.04 & 0.19 & o & 1 \\
\hline Labor force status: other & 3190 & 0.05 & 0.21 & o & 1 \\
\hline Smoking & 3190 & 0.29 & 0.45 & o & 1 \\
\hline Regular medication & 3190 & 0.34 & 0.47 & o & 1 \\
\hline $\begin{array}{l}\text { Somebody in the household is } \\
\text { sick/needing nursing }\end{array}$ & 3190 & 0.24 & 0.43 & $\mathrm{O}$ & 1 \\
\hline $\begin{array}{l}\text { Equivalent income (price adjusted } \\
2005 \text { HUF) }\end{array}$ & 3190 & 732456 & 312881 & 149016 & 3260886 \\
\hline $\begin{array}{l}\text { Value of the house (million, price } \\
\text { adjusted } 2005 \text { HUF) }\end{array}$ & 2966 & 7.56 & 6.32 & 1 & 50 \\
\hline Household size & 3190 & 3.00 & 1.34 & 1 & 8 \\
\hline Number of children in the $\mathrm{HH}$ & 3190 & 0.40 & 0.77 & $\mathrm{o}$ & 4 \\
\hline Subjective welfare status: poor & 3190 & 0.07 & 0.26 & o & 1 \\
\hline $\begin{array}{l}\text { Subjective welfare status: below } \\
\text { average }\end{array}$ & 3190 & 0.42 & 0.49 & o & 1 \\
\hline Subjective welfare status: average & 3190 & 0.46 & 0.50 & $\mathrm{O}$ & 1 \\
\hline
\end{tabular}


Subjective welfare status: above average or rich

Domicile: Budapest

Domicile: big city

Domicile: other city

Domicile: village

Inviting guests: at least once a week

Inviting guests: a couple of times a month

Inviting guests: several times in a year

Inviting guests: once a year or more rarely

Inviting guests: missing

House type: family house

House type: apartment

House type: rented apartment

House type: other

Region: Western Transdanubia

Region: Central Transdanubia

Region: Southern Transdanubia

Region: Central Hungary

Region: Northern Hungary

Region: Northern Great Plain

Region: Southern Great Plain
3190

3190

3190

3190

3190

3190

3190

3190

3190

3190

0.04

0.15

0.21

0.36

0.42

0.23

0.44

0.48

0.35

0.06

0.24

0.25

0.43

0.50

0.50

0.18

0.38

0.00

0.06

3190

0.65

0.48

0.30

0.46

0.03

3190

0.01

0.18

0.11

0.31

0.11

0.11

0.31

0.30

0.45

0.33

0.34

0.34
1

1

1

1

1

1

1

1

1

1

1

1

1

1

1

1

1

1

1 
The association between experiential and material expenditures and subjective well-being (Hungarian Household Budget Survey) - Adjusted to consider the spending of 1000 HUF (measured in equivalent monthly expenditures) on clothing as a basic need

\begin{tabular}{|c|c|c|c|c|}
\hline & & (1) & (2) & (3) \\
\hline \multirow[t]{2}{*}{ Experiential expenditures (\%) } & $\beta_{1}$ & $\begin{array}{l}0.013^{* *} \\
(0.006)\end{array}$ & $\begin{array}{c}0.022 \\
(0.017)\end{array}$ & $\begin{array}{l}0.014^{* *} \\
(0.006)\end{array}$ \\
\hline & $\rho_{1}$ & & $\begin{array}{c}0.288 \\
(0.501)\end{array}$ & \\
\hline \multirow[t]{2}{*}{ Material expenditures (\%) } & $\beta_{2}$ & $\begin{array}{l}0.015^{* *} \\
(0.006)\end{array}$ & $\begin{array}{c}0.033^{* * *} \\
(0.013)\end{array}$ & $\begin{array}{c}0.033^{* * *} \\
(0.012)\end{array}$ \\
\hline & $\rho_{2}$ & & $\begin{array}{l}0.603^{* *} \\
(0.275)\end{array}$ & $\begin{array}{l}0.589^{* *} \\
(0.281)\end{array}$ \\
\hline Controls & & yes & yes & yes \\
\hline Adjusted R² & & 0.240 & 0.241 & 0.241 \\
\hline $\mathrm{N}$ & & 3190 & 3190 & 3190 \\
\hline $\begin{array}{l}\text { p-value on test of equal } \beta \\
\text { coefficients }\end{array}$ & & 0.869 & - & - \\
\hline $\begin{array}{l}\text { p-value on test of equal } \rho \\
\text { coefficients }\end{array}$ & & - & 0.570 & - \\
\hline
\end{tabular}

Dependent variable: Life satisfaction (standardized).

Robust standard errors adjusted for clustering by household are in parentheses. Controls: gender, age, age squared, equivalent expenditures (in log form), equivalent income (in log form), feeling about household's income, education, marital status, labor force status, frequency of inviting guests, household size, number of children in the household, value of the house (in log form), type of the house, regular medication, smoking, a sick individual in the household or one needing nursing, domicile, region, and diary month.

Dummies are included for missing regressors (except for the expenditure variables).

${ }^{*} \mathrm{p}<0.10,{ }^{* *} \mathrm{p}<0.05,{ }^{* *} \mathrm{p}<0.01$ 